\title{
原 著〔実践研究〕
}

\section{学習障害児に対する動機づけ介入と計算スキルの教授}

一一相互モデリングによる㑬別学習指導を通して——

\author{
植 木 理 恵 ${ }^{1}$
}

従来の教育心理学が推奖してきた学習態度として、「内発的学学習動機」と「理解を重視する学習」の 2 点が挙げられる。本研究は, 1 人の学習障害児への引き算の個別指導を通して, これらの知見を実践 場面で活用していくにはどのような工夫が必要であるか検討したものである。介入方針としては，課題 関与的な動機づけの前に「計算が使えるようになりたい」という実用志向からの動機づけを試み，さら に理解の前段階として計算手続きの獲得を先行させた。また，その手続き教授の際には「相互モデリン グ」という介入手法を開発し試みた。相互モデリングとは，教示者と学習者が互いの思考過程を観察し 合うことによって正しい手続きを獲得しながら，効率的に自分の間違いパターンを自覚・修正するため の教育的介入法である。本研究では，この新しい介入法の提案と検討も行った。このような指導の結果， 学習者は短期間で引き算の手続きを獲得することができ，次第にその意味理解も伴うようになった。同 時に, 問題解決時の不安を自己調節する動機づけ方略を相互モデリングに取り入れることにより，自己 効力感が低く注意散漫であった学習者が, 最後まで根気強く課題に取り組むことができた。

キーワード：相互モデリング，実用志向，学習障害児，動機づけ方略

\section{問題}

\section{1．学習動機に関する実践上の問題}

学習動機や学習目標に関する一連の研究では, 成績 やそれに付随する賞罰のような, 課題内容以外のもの を目的とする学習動機と，学習プロセスや課題内容自 体に関心をもつ学習動機の 2 種類に分類し，学習者の 持つさまざまな学習動機や学習目標を分類する試みが なされてきている。例えば，それぞれ强調する点㤨 なるが，パフォーマンス目標とマスタリー目標 (Ames \& Archer, 1988), パフォーマンス目標とラーニング目標 (Dweck 1986), 内容分離的動機と課題関与的動機(堀野· 市川, 1997)，エゴ志向と課題志向 (Maehr \& Nicholls, 1980) などは，こうした分類と見ることができる。さらに， それらの学習動機のタイプと学習方略, 学業成績など との関連を調查することによって, 課題内容に関与す る動機づけを持っている学習者の方がより効果的汇学 習方略を使用し，学業成績も高い傾向があることが， Graham \& Golan (1991), 堀野・市川 (1997), 川島ら (1998), Nolen (1988), 塩見・芦塚 (1998) 等によって示 されてきている。

確かに, 課題内容自体を楽しみ, 学んでいくプロセ

1 東京大学教育学研究科
スを目的とする学習動機は, 自己学習力や生涯学習と いった視点から見ても必要不可欠なものである。しか し現実的には，そのような課題関与的，充実的な動機 が重要なことは分かっていても，実際にどのような介 入がその促進に有効なのかという，実践的な知見はま だほとんど得られていない。さらに，これまでの大部 分の研究が調査対象としているような，いわゆる普通 学級の中学生, 高校生への動機づけ介入の難しさにも 増して, 学習遅滞の進んでいる子どもや学習障害を持 つ子どもに対して，はじめから課題自体への内的な興 味を促そうとすることは，現実的にはかなり困難なこ とである。特に学習性無力感が伴っている場合は，教 師やまわりの大人の「勉強は面白いものだ」という説 得は役立たないことが多い。また，彼らは苦手な教科 の学習場面において多動や注意散漫になりやすいため, 指導の当初加ら学習の意義や内容のおもしろさに注意 を向けさせ,動機づけようと試みる事は,介入者にとっ ても容易なことではないし，同時に学習者にとっても 「やはり学習は楽しめない」「自分には不向きである」 ことを確認するような苦痛な時間を過ごさせることに なりがちである。

\section{2. 理解促進に関する実践上の問題}

また「意味的な理解を伴わない手続きの暗記は保持 
されにくい，利用しにくい」という認知心理学的な知 見も，確かに学習活動における重要な事実ではあるが， 実際的には動機づけと同様の問題を抱えている。特に 学習障害などで極度の無力感に宿っている子どもに対 して,はじめから理解してから覚えるというスタイル を取らせようとしてもうまくいかない場合が多い。彼 らはもともと課題への関心が著しく低下している上に， 認知的にも理解までにかなりの時間がかかることが多 く，そのため理解という段階にたどり着くまでの注意 力や集中力が持続しにくいからである。よって意味理 解の推進の前段階として, その水準につなげるための 何らかの介入が必要であると考えられる。例えば，ま ず問題解決の手続きを先に獲得させ，その後で理解へ と学習者を導こうとする介入方針は,このような場合 有効ではないだろうか。本研究では，このような問題 点を解決する足がかりとなる介入方法として,「相互モ デリング」という手法について，提案を行う。

\section{3. 本研究での実践的介入の方針}

本研究では以上のような教育実践上の問題点を踏ま え，1人の学習障害 (Learning Disorders) 児に引き算を 教授する過程を通して，実用志向に根ざした動機づけ と，手続きの獲得から始める学習を目的とした介入を 行い, このような介入の有効性と問題点について検討 する。それは, 課題内容や問題解決プロセス自体に興 味を持たせることが困難な览童に対して，実用志向的 な学習動機を促進することと, 理解が困難である児童 に対しては，まずはじめに計算の手続きを獲得させ， その後に徐々にその意味理解へと導く指導方針が有効 ではないかと考えたためである。

先に触れたような学習動機の対立的なとらえ方とは 別に，市川 $(1995,1996)$ は学習動機の構造をより詳細な 6 種類の志向 (充実志向, 訓練志向, 実用志向, 関係志向, 自尊 志向, 報酬志向）に分類し，それらを学習内容の重要性， 学習の功利性の 2 要因に分類したモデルを生成してい る。その中の実用志向とは,「現在行っている学習を生 活や仕事に役立てたい」という最も現実的な動機づけ の 1 つである。実用志向の学習者の目的自体は, 生活 や仕事といった課題の外部に存在するものであるが, 報酬志向のように学猊が報酬の手段に過ぎない動機づ けとは異なり，あくまでも学習の内容を生かそうとす る姿勢をとる考え方である。よって報酬志向のような 課題から分離した動機づけよりも課題関与的，充実的 な動機づけへの移行の可能性は高く, さらに, はじめ から課題関与的，充実的な動機づけ介入をするよりも， より現実的な場面での達成感や効力感に結びつきやす
いという特色があると考えられる。

\section{4. 本研究での実践的介入の手法}

本研究では, 介入の際の形態として認知カウンセリ ング (Cognitive Counseling) という手法を基盤とする。 認知カウンセリングは,「何々がわからなくて困ってい る」という認知的問題をかかえた学習者 (認知的クライエ ント)に対する個別的な相談と指導を通して, 認知心理 学や教育心理学の基礎研究と学習指導をつなぐという 趣旨で行われている実践的研究活動である(市川, 1986)。本ケースでは計算ができないというM君 (小 6) がクライエント (以下 $\mathrm{Cl}$ ) であり, 筆者が認知カウンセ ラー (以下 $\mathrm{Co})$ ということになる。ここで, Co は 2 種 類の目的を持ってカウンセリングに臨んでいる。1つ は,このような学習指導の事例を積み重ねることに よって, 上記のような動機づけや理解に関する教育心 理学の問題に対して何らかの実践的な知見を得ていこ うとすることであり，もう 1 つは $\mathrm{Cl}$ を算数の学習に動 機づけ，計算技能を支援しようとすることである。

ここで計算技能を支援し，手続きから理解へという 学習を支えることを目的として，新たな介入方法を開 発し実施した。それは，まず $\mathrm{Cl}$ が Co から正しい手続 きをモデリングによって獲得し，次に， $\mathrm{Co}$ が $\mathrm{Cl}$ の間 違いパターンをモデリングして見せるというやりとり を相互に繰り返し行う介入システムである。その介入 の構造を FIGURE 1 に示した。ここではそれを「相互モ デリング」と名付ける。このような介入の結果，力ウ ンセリング初日は計算を拒否していた $\mathrm{Cl}$ が, 8 日目に はかなり桁数の多い計算を難なくこなすようになった。 本研究ではこの相互モデリングの提案と検討も行う。

(1) カウンセラーの正確な手続きを, クライエントがモデリングする

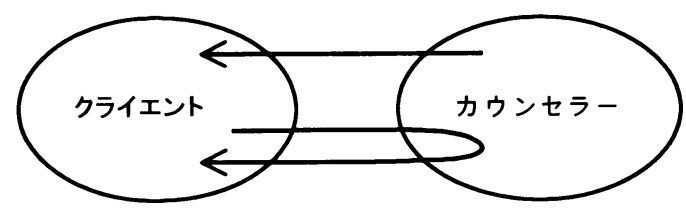

(2) クライエントの間違いパターンを, カウンセラーがモデリングして返す

FIGURE 1 相互モデリングの構造

\section{事例の概要}

\section{1. クライエントについて}

$\mathrm{Cl}$ は現在小学 6 年生の男子である。相手の質問には 答えずベラべラと独言を言い続け，急に笑い出すとい 
う風変わりな話し方が幼稚園の頃から目立ってはいた が, 小学校では普通の学級に入学した。1 人で詩や俳 句を書くことに熱中しコンクールで入賞するほどのレ ベルに達するが，算数の授業には全くついていけない。 小 2 の頃から, 特に算数の時間になると多動や注意散 漫が激しくなり，教室をウロウ口歩き始めたり，その ことを注意したら校庭に出ていったりするようになる。 この頃, 病院で学習障害(LD) と診断される。国語や社 会の成績は常に上位クラスで, 理科についても鉱石や 星の名前を先生よりも多く知っており，実験にも率先 して参加する。ただ，簡単な計算だけができないとい う状態が現在まで続いている。またこれまで専門的な 治療等は行わず, 大学生の家庭教師に計算を習わせよ うとしたが全くうまくいかなかった。どの家庭教師も 1 年生用の計算ドリルから始め, その段階からのス モールステップを試みたようだが, $\mathrm{Cl}$ の「僕は 1 年生 じゃない」という激しい抵抗によって, 机について勉 強を始めることすらできなかった。そのような状態の まま 6 年生になり, 最近は計算ができないことが原因 でいじめられるようになり,算数の授業のある日は「お 腹が痛い」と言って朝起きられなくなる。

初日は勉強部屋に入ろうとしなかったため, 近所の 公園のベンチに座って話をした。足し算と, 繰り下が りのない引き算の問題を出してみると, 時々指を使い ながらも正解を導けるが, 繰り下がりのある引き算に なるとオーバーに顔を背け, 問題に向かおうともしな い。計算ができるようになりたくないのか, 困ってい ないのか, と質問すると「僕は LD だからできないんだ よ。今さら困ってないよ。」と繰り返す。また日本史や 理科の実験の話などはとてもよく喋るが，少しこちら が計算の話を始めるととたんにそわそわし始め, 話を そらしたり, 立ち上がってその場を去ろうとする。社 会や国語に関する知識は中学生レベル, しかし計算能 力は小 2 レベル, という学習障害児に特有とも思われ るアンバランスさが顕著であり, そのためか, 算数に よって自尊心が傷つけられることに非常に敏感である。

\section{2 . 指導仮説}

$\mathrm{Cl}$ は言語能力は標準的であるが, 計算の仕組みの理 解が困難であり, 計算の修得に対する学習動機が著し く低下している。また, 算数によって自尊心が傷つく ことに大変敏感であり，集中力も持続しにくい。した がって,この Cl にははじめから課題内容へ着目させよ うとするのではなく，買い物という計算の実践場面を 通してその実用性の認識させることが，学習動機を高 める事につながりやすいと思われる。また, はじめか
ら計算のしくみの意味理解を強いることは避けて, ま ずは相互モデリングを通して計算手続きを獲得させ, そこから意味理解へとつなげていくような指導方針が 有効なのではないかと考えられる。

\section{3. 介入計画}

認知カウンセリングの回数と日程については,Co と $\mathrm{Cl}$,そして $\mathrm{Cl}$ の母親の 3 名であらかじめ話し合いをし た。その結果, $\mathrm{Cl}$ の「全部で 8 回くらいだったら来て もいい」「しかし毎日来るのは難しい」という希望を尊 重し，1日おきに 8 回のカウンセリングを行うという 計画をたてた。その際, その 8 回のカウンセリングの 中で $\mathrm{Cl}$ を計算の学習に動機づけ,最終的に手続きを獲 得させることを目標とするため, 前半の 4 日間で動機 づけを, 後半 4 日間で引き算の手続きの獲得を支援す るという計画を, 大まかな目安とした。介入時の手法 としては，まず買い物場面での経験を通して実用志向 からの動機づけを促進し, その後相互モデリングに よって計算手続きの獲得を援助する。最終的には, 計 算を利用して 1 人で買い物ができるようになることを 目標とした。

\section{事例の経過}

\section{1. 動機づけ期間}

\section{1）買い物場面での実用志向の促進}

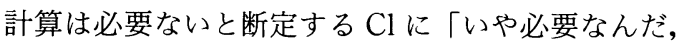
この先困るぞ」と説得しても全く聞く耳は持ってもら えない。また，算数の楽しさを感じる，という状態ま でにはかなりの時間を要すと思われ, 注意散漫な $\mathrm{Cl}$ を はじめから課題関与的，充実的な動機づけの段階にま で引き上げようとしても, 課題に向き合おうとさえし ない。 $\mathrm{Cl}$ はこれまで，このような類の説得や助言にう んざりしているようである。そこで, 計算手続き獲得 への動機づけの前段階としてまず必要不可欠なのは, $\lceil\mathrm{Co}$ は $\mathrm{Cl}$ の計算が嫌いという気持ちに共感できる人 である」ということのアピールであると考え, 次のよ うなやり取りから, 動機づけのカウンセリングへの導 入を行った。

\section{(介入 1 日目・公園にて)}

$1 ＼mathrm{~ Ｃ o r ~ 「 H 君 か ゙ 嫌 い な 引 き 算, ~ 何 て ゙ 学 校 の 先 生 は 必 ~}$ 死に教えたがるんだろうね?」

$2 ＼textrm{C l}$ 「ぜーんぜん要らないのにね。ぜんぜんね。」

3 ；Co 「そうだねー。何の役に立つっていうんだっ て感じ！?」

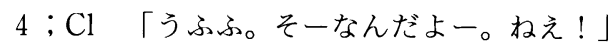


5 ；Co 「僕をいじめるためかー？!」

$6 ; \mathrm{Cl}$ 「そうそう。」

このような雾囲気づくりから始めて, その後 4 日間 は算数の勉強をしようとは誘わず，また計算は楽しい とも役立つとも助言せず，近所のスーパーで買い物を 繰り返し行った。計算の実用性を実感させ, 実用志向 を促す場面の一つとして, 買い物場面は有効であると 考えたからである。買い物の手続きとしては，まずあ らかじめ料理のメニューを決め, どんな材料が必要か 広告を見ながら 2 人で選び, お遣いメモを $\mathrm{Cl}$ に書かせ た。例えば, 介入 4 日めには野菜炒めというメニュー を設定したが，その場合 $\mathrm{Cl}$ は「ピーマン（198円）を 2 袋，ニンジン $(200$ 円) を 1 袋，キャベツ $(230$ 円)を 1 個」 と広告から材料を選んでメモをする。そのメモをもと にCo は以下のような要領で, 引き算の実用性を感じ られるような課題設定を適宜行っていった。

\section{（ 4 日め・買い物の計画場面）}

7 ; Co 「奥さん, 今500円しかないんですの。全部買 えるかしら?」

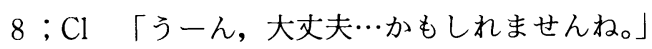

7 では「500円以内で」という枠を提案し, わざとメ モの野菜を全て買えないような状況を作り出している。 4 日間の買い物を通して, このように Co は $\mathrm{Cl}$ が設定 したメニューを見た後で，わざと金額が不足するよう に制限を与えていく。するとはじめの 3 日間は，うま く制限金額の中で計画を立てられないと,メニューと 関係のない品物を買おうとしたり, 問題解決を回避し ようとする態度がみられた。しかし，Co と一緒に計画 を立てて買い物を試みるということ自体は楽しんでい るようであり，毎回時間どおりに来談してきた。そし て，4日めには「今日こそ，メニューの材料をうまく そろえる」と，買い物という問題解決に意欲的な態度 を示していた。

またこの 4 日間を通して， Cl は Co の 7 のような質 問に対して，計算して足りるかどうかを確かめようと はせず，8のように大丈夫かもしれない，という直感 的な返答をする。そこで, 実際にスーパーでメモどお りの品物を買い物かごに入れ，Cl に500円を持たせて レジに並ばせた。無論レジではお金が足りず, $\mathrm{Cl}$ は少 し離れて見ているCo のもとへ戻って来た。
(4 日め・スーパーにて)

9 ;Co「足りなかったの? 困ったねえ。もう一度メ ニュー立て直しかな。」

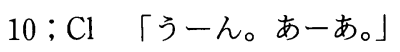

11 ; Co 「あーあ, だね。ㅊえーっと，500円以内で野 菜炒めの材料を買うんだよねー。」

$12 ; \mathrm{Cl}$ 「あ, 何かちょっと削らなきゃ。ああ!ピー マンを 1 個減してみたらいいかも!」

$\mathrm{Cl}$ は再び直感によってピーマンを 1 袋戻し, レジに 並び直した。このように彼は，どうにかして計算して 考えるという方略を避けようとする。しかし Co は11 のように共感的な雾囲気で問題整理に徹し, $\mathrm{Cl}$ の使お うとする直感方略を非難したり，また計算を勧めたり， 間違いを指摘したりはしないようにした。それは, 計 算を避けて直感により買い物する事の限界を, $\mathrm{Cl}$ 自身 に少しずつ実感してもらうためである。またそれと同 時に, 彼の動機づけに働きかけてその後の手続きの習 得の段階まで導くためには, 彼なりに思いついた直感 方略を一度受け入れ，その方法に徹底的につき合う中 で, 自尊感情や効力感を持たせることが必要不可欠で あると判断したためである。直感的にピーマン 1 袋を 削ってもさらに500円では足りなかった $\mathrm{Cl}$ は, 再び 戻ってくる。

\section{(4 日め・スーパーにて)}

$13 ＼textrm{C l}$ 「また500円じゃ足りないって言われたよ。」

14 ;Co 「じゃあ,どうしょうか。さっきみたいにパッ と何か 1 つ削ってみる?」

$15 ； \mathrm{Cl}$ 「うーん。またそれでも足りなかったら，も う恥ずかしすぎる。疲れた。」

16 ：Co 「そうかー。…今って, 何が分かったらすご く助かるのかなあ？」

$17 ; \mathrm{Cl} 「 え っ と, \cdots と ゙$ 野菜をやめたら 500 円以内に なって…」

18；Co 「うん。そうだよねー。しかもできるだけいっ ぱい買いたいよねえ…」

$19 ＼mathrm{~ C l ~ 「 う ん 。 あ あ … 500 円 を き ゙ り き ゙ り て ゙ 使 え る よ う ~}$ に, 調べないと。」

20 Ｃｏ「パッと削るんじゃなくて，調べる，のか。 なるほど。うーん,でもどうやって調べるの？」

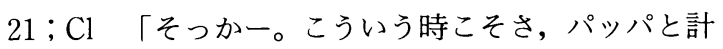
算できたら楽だと思うけど…」」 
なるかという自信はなくとも，ともかく計算という道 具を使えるようになればとても便利であることに $\mathrm{Cl}$ は気づいていく。結局 4 日間とも買い物はできないま ま終わったが (計算抜きでは困難な問題をCo が設定していっ たため), 彼なりの直感方略をCo と共に存分に試した 結果であるため自尊心が満たされ，取り組んでいる事 への興味や集中力が高まっている。このように，計算 という手段の実用性に自分で気づくことのできる状況 と，既存の方略を何度試しても，それでは不十分であ る事を実感できる状況，という 2 つ条件が満たされ ていることによって, 実用志向の学習動機を持つこと が可能になると考えられる。また，特に $\mathrm{Cl}$ のように自 尊感情に敏感な学習者の場合は, 既存の方略をはじめ から否定されるのではなく，その方略にCo が十分つ き合ってくれるという体験が，学習意欲を高める重要 な基盤となると考えられる。

\section{1. 買い物場面から計算の学習場面へ}

カウンセリング 4 日目には机について「引き算の仕 方を教えて欲しい」と言うようになった。また，例え ば宅配ピザの広告を見ながら「もし2000円しか持って いなかったら，どんなピザが買えて，どんな飲み物が 注文できるかなあ?」などど現実場面に即した問題設 定を自発的に行って考えるようになった。しかし手を 動かして式を書いたりはせず，数字をじっとにらみつ けているだけである。「他の小 6 は皆, 筆算の形に書か なくても暗算によって引き算くらいできている。だか らいちいち書くのは格好悪い」と考えているようであ る。

( 4 日め・買い物から戻って)

$22 ; \mathrm{Cl}$ 「かっこわるいよ。筆算は幼稚な感じだから ね。恥ずかしいよ。」

23；Co「あはは。なるほど，そうなのかあ。」

ここでもCo は買い物の時と同様に，筆算という方 略を直接的に勧めることはせず，数字をじっと見つめ る，という $\mathrm{Cl}$ の方略を「なるほど」と感心してみせ， 受け入れるようにした。そして， $\mathrm{Cl}$ がそこで使扔うと している方略を， $\mathrm{Cl}$ 自身に見えるような形にして フィードバックする。つまり, $\mathrm{Co}$ が $\mathrm{Cl}$ のモデリング をして見せるのである。これは, FIGURE 1 の(2)に相当 する介入である。この場面では, Co も膝の上に手を置 いて数字をじっとにらみつけ,「2000円しか持っていな かったら…」と念力をかけるように唱えながら考え込 んで見せた。

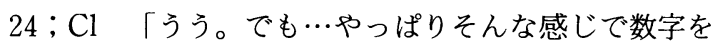
見つめてても分かる訳ないか。あはは。なんか 筆算よりも,じーっと見てる方がもっとかっこ 悪いかも。意味ないしね。」(2000-1500と筆算 の形に書く。)

25 ；Co 「ああ，筆算の形に書いてみるのねー。」

$26 ＼textrm{C l}$ 「あ一あ。ふー。やっぱりね。0から5引け ないからもう終わり。駄目だー。」

27 ：Co 「あはは。見て。1 億円で 5 円のチョコを買 いました。」(100,000,000- 5 と筆算の形で書 く)

28 ；Co 「あーあ。ふー。0 から 5 引けないから買え ませんでした。駄目だー。」

$29 ; \mathrm{Cl}\lceil お$ 姉さんはバカ。 0 からじゃなくて1億か ら 5 引くんだよ一。あっ!それって僕のまちが い。」

$\mathrm{Cl}$ は筆算の形にしたとたんに, 2000からそれより小

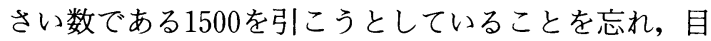
の前の 0 から 5 が引けないから自分にはできないと思 いこみ,すぐに投げ捨ててしまう。しかし Co が彼の思 考過程を推測し，「 1 億一 5 」という大小の差がより極 端な同型の問題を用いて $\mathrm{Cl}$ の思考をモデリングして 見せれば，すぐに自分の誤りに気づくことができるの である。このように，同じような構造でかつ間違いが はっきりと分かるような問題を使い,それを $\mathrm{Cl}$ と同じ パターンで間違えて解いてみせることによって, $\mathrm{Cl}$ が 自分の間違いに気づきやすい状況を作っていく工夫が ここでは重要である。

このようなやり取りを 5,6 度繰り返すうちに, $\mathrm{Cl}$ は自分も落ち着いて考えればできるのだという効力感 を高め，また課題への注意を持続できるようになって きた。そして漠然とした「買い物をしたい」という動 機だけではなく,「繰り下がりのある引き算ができるよ うになりたい」という実用志向の学習動機が同時に高 まり，計算手続きの修得への意欲が徐々に高くなって いったようである。

\section{2．相互モデリングによる手続きの獲得期間}

\section{1）正しい計算手続きの学習}

5 日目からは「繰り下がりのある引き算が，筆算で 計算できるようになる」という明確な目標を掲げて取 り組んだ。その際， $\mathrm{Cl}$ の自尊感情や集中力に配慮し て, 取り扱う問題は小 1 用の計算ドリルではなく,スー パーの広告やレシートにある数字から Co が問題設定 につなげるようにした。また, $\mathrm{Cl}$ 一人で計算させる場 
面ははじめは避け,Co もノートを作って同じ問題を解 くことによって $\mathrm{Cl}$ の不安感にも配慮した。

またここでは，動機づけ期間に行ったモデリングを より相互的に用いて, 引き算の手続きの獲得を目指し た。まずはじめにCo が, 引き算をする際の自分の思考 過程を声に出しながら行って見せ, 正しい計算手続き を $\mathrm{Cl}$ がモデリングしやすい状況を作る。これは FIG. URE 1 の(1)にあたる介入である。

\section{( 5 日め)}

$30 ； \mathrm{Co}$ 「引き算する時のお姉さんの頭の中は, こう いう風になっているよ。えーっとまず問題を ちゃんと見てっと。102-15か。まず1の位の 2 から 5 を引くんだけど, うーん・...引けないか ら困ったなあ。」

このようにCo がまず問題にきちんと向き合い，そ して困難にぶつかっている様子を $\mathrm{Cl}$ は興味深げに観 察している。ここで, Co は計算手続きに関する思考だ けではなく, 困ったなあ, というような情動表現も共 に行う。それによって Cl はCor同一化しやすくな り，またこれなら自分にも同じょうにできそうだ，と いう自己効力感が高まり，モデリングに集中しやすい 状態になる。

\section{( 5 日目つづき)}

31 ；Co 「ああ！こういうときは10の位から借りれば いいんだよね。2 から 5 を引く訳じゃなくて， 102全体から 5 を引くんだから, 借りてきたっ ていいに決まってるもんね。うーん…でも10の 位は0だから借りられないじゃん。どうしょう …でも焦んなくてもいいんだ。あきらめちゃダ

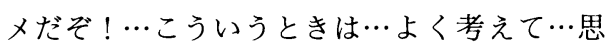
い出した！100から借りればいいんだよねー。 別に大したことないじゃん。落ち着いて考えれ ば大丈夫なんだよね。で, 次にすることは…」

また, $\mathrm{Cl}$ は思考過程やその時の情動と共に,このよ うな自己制御のプロセスも同時に言語化して見せる。 壁にぶつかったらすぐに投げ出してしまう $\mathrm{Cl}$ が，Co が側で励まさなくても自分で自分を鼓舞し，問題に集 中し続けることができるようにするためである。 $\mathrm{Cl}$ は, 楽しそうにCo の思考過程をモデリングし始める。
問題を見よう。102-15か。まず 2 から 5 を引 くんだけど,うーん困ったなあ。でもあきらめ ないんだよ。大丈夫だからね。ああ，こういう ときは10の位から借りればいいんだよねー！ そして次に…」

このようなやり取りを, 問題を変えながら繰り返し 行った。途中で $\mathrm{Cl}$ がつまずいたり，モデリングしてい る内容を忘れたりするたびに，Co は「えーっと次はど うするんだっけ。さっきまでできてたんだから，思い 出せるはずだなあ。」というように, さらに自分の気持 ちを落ち着け，考えている様子を観察させる。

それでも $\mathrm{Cl}$ が計算手続きを思い出せない場合は,再 び30，31のように正しい手続きのモデリングを促した。 このようなやり取りを繰り返して約 30 分後には, $\mathrm{Cl}$ は Co の手助けなしで最後まで問題に取り組み, 正解を導 くことができた。また，手続きを忘れてつまずいても， 以前のように投げ出すことはなく, 不安を自己制御す る発言を行うようになった。

\section{2）誤った手続きパターンへの気づきと修正}

$\mathrm{Cl}$ が Co の思考過程をモデリングする事によって正 確な手続きをある程度獲得したので，6日めにはその 定着を測るため, 今度は逆に $\mathrm{Co}$ の方が $\mathrm{Cl}$ の誤りパ ターンをモデリングして, その様子を観察させた。但 しここでCo は誤りという行動自体を真似るだけでは なく,その背後にある $\mathrm{Cl}$ の思考過程を推測し言語化し て見せることが重要である。例えば $\mathrm{Cl}$ が $23-7=13$ と いうような間違いを何度か繰り返したら，同じような 間違いを表面的に真似るのではなく，次のように思考 過程の推測を伴ったやり取りを行う。これは FIGURE 1 の(2)にあたる介入である。

\section{( 6 日目)}

33 ：Co 「えーっと，H君の頭の中はこんな風になっ てたのかな？まず問題を見てっと。23ひく7 か。1の位の 3 から 7 は引けないので…20ひく 7 は13。簡単!つまり $23 ひ く 7$ も13です。」

$34 ; \mathrm{Cl}$ 「えー! 違いまーす。」

35 ; Co 「違わないよ。どこが違うんだよー。」

$36 ; \mathrm{Cl}$ 「最後に13に 1 の位の 3 を足してあげるんで すよー。23から引いてるだもん。…ああもう！ 僕は最後に 1 の位の数を足してあげるの,いつ も忘れるんだ。」 
形で言語化して見せれば, $\mathrm{Cl}$ は自分の思考過程の誤り に，かなり敏感に気づくことができる。

以上のように，まず $\mathrm{Co}$ は， $\mathrm{Cl}$ に正しい手続きをモ デリングさせる。そして，そこで得たものを使って問 題を解かせる中で, $\mathrm{Cl}$ の誤りパターンを見つけて, 今 度はそれをCo の方がモデリングして返し，誤りへの 気づきを促していく。このような相互的なモデリング を繰り返し行った結果，カウンセリング 8 日目には, 12桁－12桁という大きな桁の引き算でも，正解を導け るようになった。

\section{1）自己説明による計算手続きの確認}

カウンセリング最終日は,引き算の手続きを $\mathrm{Cl}$ に自 己説明させた。その際Coが「どうやって考えるか説明 してごらん」というような教示の仕方をしても， $\mathrm{Cl}$ に は敷居が高く感じられ「説明できない」で終わってし まうと考え, $\mathrm{Co}$ が $\mathrm{Cl}$ のクラスメートであるという役 割を演じながら自己説明につなげていくように工夫し た。以下のやり取りは「106-9」をクラスメート役の Co が解いてみせる場面である。その際にわざと $\mathrm{Cl}$ の 間違いパターンを盛り込み,それを $\mathrm{Cl}$ 自身に注意させ る。

( 8 日め)

37 ; Co 「H君，この問題教えてくれよ。ええつと， まず，1の位は 9 から 6 引いて 3 でしょ？」

$38 ； \mathrm{Cl}$ 「違うよー！。106から 9 引くんだから，まず は 6 から 9 引くんだろ。じっくり問題を見なさ いよ。」

39 ; Co 「あ,そうか。じゃあ100から借りてきて 9 引 く。で, 答えは 1 。

$40 ； \mathrm{Cl}$ 「違う違う！君はバカだなあ。最後に 1 の位 の 6 を足してやるんでしたね。忘れちゃだめ だ。」

41；Co 「うわーそうか。頭いいなあ。もう1 回最初 から教えてよ。ねえ頼むよ。」

42 ～Cl 「うふふふふ。まずねー。6から9を引くとき は…」(得意そうに説明を始める)

$\mathrm{Cl}$ は分かりやすく手続きを説明でき，さらに自分の 間違いパターンを挙げて「これこれに気を付けよ」と 注意を促すことまで行った。また「数の仕組みって結 構おもしろいね」というような課題内容への興味を示 すようになり，計算の成り立ちに関する質問をするよ うになった。それと同時に，相互モデリングのはじめ
の方の $\mathrm{Cl}$ の発話は「次はこうしてその次はこうする」 という手続きに関するもののみであったが，最終日の 自己説明では「〜だから…して，次に〜だから…」 いうように手続きの意味や理由も盛り込んだ発話が多 くなっていた。計算の手続きのみではなく，次第にそ の仕組みの理解にも注意が向くようになった様子がう かがえる。

最後に $\mathrm{Cl}$ 一人で計画を立てて実際に買い物を行い, そこでカウンセリング終了とした。最終日に再び買い 物を行ったのは，カウンセリング当初はうまくできな かった事が，計算という道具の使い方を知る事によっ てできるようになったという効力感を $\mathrm{Cl}$ ととに味 わい, 今後の学習の動機づけへとつなげていって欲し いと考えたためである。

\section{まとめと考察}

\section{1. 動機づけ期間について}

1）「手続きから理解へ」という方向の介入

カウンセリング前半は，実際の買い物を通して，計 算の実用志向を高めることを目標とした。最初は「買 い物で使えるようになりたい」という動機で $\mathrm{Cl}$ は引き 算の学習を始めたが，次第に，計算自体の楽しさもま た重要な学習動機となっていった。それは，使えるよ うになりたいという実用志向の高まった状態の $\mathrm{Cl}$ 対して，はじめから計算手続きの意味を理解させよう とするのではなく，手続きの具体的な方法を教授する ことによって，自分にもできたという達成感や楽しさ を感じさせる事から始めたためであろう。もし，学習 者がはじめから課題関与的，充実的動機を高く持って いるのであれば，手続きの意味理解を先行し，その上 で計算方法を覚えるという学習が効果的になると思わ れるが, $\mathrm{Cl}$ のように主に実用志向によって学習動機が 支えられている場合は，手続き獲得先行の介入の方が 抵抗なく受け入れられる。特に， $\mathrm{Cl}$ のような学習障害 や学習遅滞によって動機づけが著しく低い学習者の場 合は，まず実用志向を高め，手続きを獲得させること によって，次第に効力感や楽しさを感じることができ るようになり，そこではじめて課題関与的，充実的な 学習動機への移行が可能になってくると考えられる。 つまり, 充実志向の強い学習者や学習領域には理解先 行を, 実用志向の強い学習者や学習領域には手続き先 行を，といった個人別，領域別の学習動機に合わせた 介入の工夫が重要であると思われる。

2）実用志向を支えるCo との関係づくり

また, Co の意図としては実用志向という動機づけを 
高めるということに焦点を当てていたが, 実際は $\mathrm{Cl}$ の 自尊心や効力感に配慮し, 直感方略などを受容しよう と努めた Co との関係志向に支えられて動機づけられ た側面も大きいと思われる。つまり「この人となら頑 張って計算を覚えよう」という形でも $\mathrm{Cl}$ は動機づけら れているということである。実際に，計算の実用性を 実感する段階に至るまで $\mathrm{Co}$ は $\mathrm{Cl}$ との良好な関係づ くりを無意識のうちに行っていた。例えば,「算数が苦 手と自分でも思ってはいるが，それを指摘されると深 く傷つく」といった $\mathrm{Cl}$ の複雑な気持ちに共感しょうと 試みたり, $\mathrm{Cl}$ の使う既存の直感方略を否定したり説得 して変えさせようとはせずに，その方略の不便な点に 気づきやすいような学習環境を設定していく，という ような介入の工夫が, 結果的に $\mathrm{Cl}$ との良好な関係につ ながっていったと考えられる。今回のカウンセリング では実用志向による動機づけが効果的であったが，そ れはその前提として関係志向という動機づけも同時に うまく働いていたからであろう。つまり介入者との人 間関係が基盤となって, はじめて実用志向という学習 動機が効果を持つと思われる。

\section{2. 相互モデリングの提案と検討}

相互モデリングとは, 学習者が教授者から正しい手 続きをモデリングによって獲得し, 次に, 教授者が学 習者の間違いパターンをモデリングして見せるという やりとりを，相互に繰り返し行う介入システムである。 本研究では 1 人の学習者への認知カウンセリングを通 して，このような新しい教育的介入法を提案し，その 効果を検討することを目的の 1 つとしている。

\section{1）従来のモデリング学習との違いと効果について}

Bandura ら (1963) は, 直接自らが強化を得ることが なくても, 他者の観察のみによって学習が成立するこ とを強調し，これをモデリング (観察学習) と呼んだ。 そして攻撃行動のモデリング実験では, 大人のモデル が攻撃的な行動をとるのを観察した子どもたちは, モ デルを観察しない子どもたちに比べて攻撃行動を多く 示すことが見いだされた。今回提案する相互モデリン グと, このような従来のモデリングとの大きな違いと しては, 次の 3 点が挙げられる。

第 1 に, 相互モデリングにおいては, 攻撃行動など のような行動レベルのモデリングのみではなく, 思考 パターンのような認知レベルのモデリングが成立する ことを目指している。例えば数学などの学習場面にお いて, 正解を導くまでの熟達者の行動のみを観察して いるだけでは，子どもがそこから手続きや考え方のパ ターンを抽出し習得するのはかなり困難であろう。し
かし，30や31のように, 教授する側が自分の思考過程 を詳しく言語によって表現しながら解いて見せれば, 学習者は問題解決の際のモデリングが行いやすくなる。 そのような要因によって, 本ケースのような学習障害 をもつCoでも，比較的短時間で正しい手続きをモデ リングする事ができたと考えられる。

第 2 に, 相互モデリングは, モデルから新しい行動 を学習するのみでなく, $\mathrm{Co}$ が $\mathrm{Cl}$ の間違いパターンを モデリングして見せることによって, 自分自身の間違 いに気づき, 修正していくという学習が同時に行われ るという点が大きく異なる。まず正しい手続きの思考 過程をモデリングし, 次に, そこで得た知識を使って 問題を解く中で, 今度は自分の間違いパターンを認識 し修正する。このような 2 方向のモデリングを組み合 わせることによって, 学習者にとって馴染みの薄い領 域でも効率的に学習する事ができると考えられる。

第 3 に, 相互モデリングという学習形態は観察によ る学習以外にも, 次のような心理的効果をもつと考え られる。まず, Co も $\mathrm{Cl}$ と横に並んで同じ問題を声を 出しながら解いているという状況は, 苦手科目に立ち 向かう $\mathrm{Cl}$ に連帯感や安心感を与える。その結果, カウ ンセリング中は $\mathrm{Cl}$ が注意散漫や多動になることがほ とんどなかった。また，はじめは正しい手続きをモデ リングさせる Co の発話が大部分を占める状態から, 次第に36のような形で $\mathrm{Cl}$ の方が Co に間違いを指摘 する場面が増加していくため, 自己効力感も同時に高 まると考えられる。さらに, 不安などのネガティブな 情動を,「焦らなくても大丈夫なんだよ」というよう に, 発話によって自己制御していくプロセスを同時に モデリングすることによって, 学習時の感情制御スキ ルが身に付くようである。つまり，280ように Cl が問 題にじっくり取り組まず，すぐにあきらめてしまう様 子をCo はモデリングして見せ, その後, 反対に31のよ うに自分の効力感ややる気を鼓舞している様子を観察 させる, という双方向のやりとりの中で, $\mathrm{Cl}$ は問題解 決中の不安などを制御するスキルを身につけていった と思われる。Cl は計算場面だけではなく, 他の教科の 学習をするときも発話による不安感情の自己制御を行 うようになり, 学習全般に対して以前よりも注意力が 持続するようになった。また，算数への取り組み方が 以前よりも積極的になり, 自発的に思考過程を発話し たり, 不安を自己制御したりする様子が, 学校でも見 られるようになった。

2）相互モデリングによる「手続きから意味理解へ」 さらに, カウンセリング当初の目的は, とにかく手 
続きを記憶するということに焦点が絞られてあったが， 結果的には $\mathrm{Cl}$ は引き算の仕組みを理解した上で計算 を行うようになっていた。相互モデリングのはじめの 方の $\mathrm{Cl}$ の発話は「次はこうしてその次はこうする」と いう手続きに関するもののみであったが, 最終日の自 己説明では「〜だから…して，次に〜だから…とい うように手続きの意味や理由も盛り込んだ発話が多く なっていた。正確な手続きをモデリングさせる際に， 例えば「一の位から引けないときは隣から借りよ」と いうような手続き的知識だけでなく，310ように「全 体から引くわけだから」というような理由も無意識に 盛り込んだ発話をしていたため，意味的な理解も同時 進行したのであろう。今後は, Co がより意識的に手続 きの理由や意味などを発話に盛り込んでいくことに よって, 手続きの獲得のみではなくその手続きのもつ 意味理解も同時に深まるような相互モデリングが可能 になると考えられる。

\section{3）教育実践場面への適用について}

この介入方法が最もその特長を発揮するのは, 例え ば認知カウンセリングのような個別指導の場面である と思われる。特に, 学習不振の子どもに対して, 教師 が補習のような形で相互モデリングを用いれば，本 ケースで見られたような効果が期待できるであろう。 但し本ケースの $\mathrm{Cl}$ は, 言語化という方法が学習方法と して適合している言語性能力の高いタイプの学習障害 児であった。また，大小関係などの数量概念に障害は なく,もともと持っていた数の理解が基盤となって, 手続きの獲得が円滑に行われたと考えられる。した がって, 数量概念や短期記憶などに問題を持つ他の夕 イプの学習障害児には, この方法が同じように効果を 持つとは言えない。つまり相互モデリングは, 学習者 の特性を考慮した上で用いる必要があるだろう。また， 学習障害児ではなくとも, 学習への動機づけや自己効 力感の低い学習者の場合は, 教授者に一方向的に教え られるという形を取るよりも，同じ問題に向き合って モデリングし合うという学習形態の方が,より課題へ の集中力や興味が持続しやすくなるであろう。但し， 集団授業では個々の学習者の思考過程を 1 人の教師が 同時に推測してやりとりする事は困難であるので，そ こで効果的に用いるには何らかの工夫を考える余地が ある。例えば，学習方略の 1 つとして相互モデリング の方法を教室で紹介し, 学習者同士の共同学習におい て用いることは，それがスムーズにできるようになれ ば大変効果的であると思われる。相手がどのような思 考過程をたどって答えを出したのかという推測は, 教
わる方のみではなく教える側にとっても, 課題内容の 深い理解につながる。また発話による思考過程の表現 によって, メ夕認知やモニタリング能力が高まること が期待される。そのような利点が十分引き出されるよ うな学習者同士の組み合わせや，適切な課題などの状 況設定について，さらに研究を深めるとともに，動機 づけや手続き獲得の問題に提言できるような指導事例 を積み重ねていくことが今後の課題である。

\section{引用文献}

Ames, C., \& Archer, J. 1988 Achievement goals in the classroom : Students' learning strategies and motivation processes. Journal of Educational Psychology, 80, 260-267.

Bandura, A., Ross, D., \& Ross, S.A. 1963 Imitation of film-meditated aggressive models. Journal of Abnormal and Social Psychology, 66, $3-11$.

Dweck, C.S. 1986 Motivational processes affecting learning. American Psychologist, 41, 1040 -1048 .

Graham, S., \& Golan, S. 1991 Motivational influences on cognition : Task involvement, ego involvement, and depth of information processing. Journal of Educational Psychology, 83, 187 -194 .

堀野 緑・市川伸一 1997 高校生の英語学習におけ る学習動機と学習方略 教育心理学研究, 45, 140 -147 .

市川伸一 1989 認知カウンセリングの構想と展開 心理学評論, $32,421-437$.

市川伸一 1995 学習動機の構造と学習観との関連 日本教育心理学会第 37 回総会論文集, 177

市川伸一 1996 学習と教育の心理学(現代心理学入 門 3）岩波書店

川嶋涼子・鎌原雅彦・高木尋子・高梨 実・竹綱誠一 郎 1998 小学校における学級雲囲気と学習 行 動の継時的変化に関する研究 (その 2) 日本教育 心理学会第 40 回総会論文集, 319 .

Maeher, M., \& Nichols, J. 1980 Culture and achievement motivation : A second look. In Warren (Ed.), Studies in cross-cultural psychology. New York : Academic press. Pp.221267.

Nolen, S. 1988 Reasons for studying 
Motivational orientation and study strategies.

Cognition and Instruction, 1988, 5 (4), 269-287.

Lawrence Erlbaum Associates, Inc.

塩見邦夫・芦塚文也 1998 小学生の学業的目標に対

する知覚と原因帰属が自己調整学習方略に及ほすす

影響日本教育心理学会第 40 回総会論文集, 292.
謝辞

本論文の作成にあたり御指導くださいました，東京 大学の市川伸一教授に感謝致します。また, 貴重なコ メントを頂きました認知カウンセリング研究会の皆様 にも，心よりお礼申し上げます。

(1999.9.17 受稿, 2000.6.12 受理)

\section{A Motivational Intervention Teaching Subtraction Skills to a Child with a Learning Disorder : Individualized Instruction by Interactive Modeling}

RIE UEKI (GRAdUATE SCHOOL of EDUCATION, UNIVERSTTY OF TOKYO) JAPANESE JOURNAL OF EDUCATIONAL PSYCHOLOGY, 2000, 48, 491-500

In the field of educational psychology, many findings have shown that "intrinsic motivation" and "understanding centered learning" were desirable attitudes that enhanced learning. The present study examined a teaching method for implementing these findings in practice in individualized instruction of an elementary school sixth grader with a learning disorder. In this case, the boy's motivation came from his expressed intention : "I want to be able to use subtraction for some real purpose." The enhancement of his motivation, task-oriented motivation (learning subtraction in the training setting), and the acquisition of subtraction procedures were conducted as part of training, with the goals being for him to be able to subtract, and then to understand the process. During instruction, an intervention technique called "Interactive Modeling" was developed and tried. Interactive modeling is a new educational intervention method that teaches the learner to become aware of error patterns, and prompts the learner to correct them while the teacher and the learner are observing each other. As a result of this intervention, the student was able to learn quickly how to do subtraction, and gradually came to be interested in the meaning of the procedure of subtracting. At the same time, because the student was taught during the modeling how to control his anxieties when working on solving problems, he became able to concentrate on the problems and work patiently.

Key Words : interactive modeling, practical intention, child with a learning disorder, self-motivational strategy 